\title{
Collaborating Teacher Librarians with English Department Teachers : Useful Online Databases for English Presentation
}

\author{
Tamao Eryu \\ Meiji University Meiji High school \& Junior High School \\ 4-23-25 Fujimicho Chofu-shi, Tokyo 182-0033 \\ Japan \\ eryutamao@hotmail.com
}

Keywords: Collaboration, Teacher Librarian, Online newspaper databases, School Library,

In this study, I will describe how a teacher librarian collaborated with English department teachers to help students make foreign (English) language presentations. The teacher librarian and English department teachers shared the same goals, resulting that students got different helps in the school. This collaboration derived from a previous collaboration of English Extensive Reading that the Meiji University Meiji High School Meiji Junior High School library did with the English Department.

Meiji University Meiji High School holds English presentation contests every year. Students must make a five minute presentation in English. The presentation is judged by their English skills, contents and general impression. This means that finding good and relevant topics and making a logical presentation is more essential than just giving a good 'English speech'.

Finding English references and preparing a five minute presentation is a high requirement for Japanese High School students. Therefore, English department teachers and the teacher librarian need to work together to aid the struggling students. 
There are over 6,000 English books in the school library but they are mostly fiction which means students need to find ideas and references not just in books but from other sources and in both Japanese and English. This is where the teacher librarian is needed.

The teacher librarian taught the students how to use the newspaper databases which the school has prepared in the school library. Two famous online newspaper databases (Asahi Kensaku-kun, School Yomidasu) are very helpful for students. These online newspaper databases provide both Japanese and English articles. From these, the students also learn useful phrases and terms that can be used for the presentations.

Then in class, the English department teachers teach students how to prepare their presentations, such as making outlines, writing speech scripts and making power point slides. The teacher librarian supports students individually out of the class in the library.

To allow the students to get smooth help both in the classroom and the library, it is important for the teacher librarian and the English department teachers to have frequent meetings. Both the teacher librarian and the English department teachers must know the purpose of the research, find out what is needed and what can be provided in the library and the deadline of each stage.

This collaboration enabled students to find a wide range of topics, getting better resources and think deeply about their topics through them, helping to make their presentations easily but at a high standard. The Students gained both English skills and information literacy.

\section{Biographical note}

Tamao Eryu has worked as a teacher librarian at Meiji University Meiji High School Meiji Junior High School (MKC) in Tokyo since 2007. She received her master's degree from the Graduate School of Library, Information and Media Studies. University of Tsukuba. Her main research is Teacher/Teacher Librarian Collaboration. Almost every day she has lessons with teachers and enjoy them. She wrote Information Literacy Teaching Activities for Teacher Librarian's Lessons. School Libraries in Tokyo, 2009, (45)22-31. Trend of Meiji High School Students' Graduation Thesis. Meiko Kenso.2011, (9)3-8. Eryu,T. \& Muramatsu,N. English Extensive Reading in MKC; A study on how students choose books. Meiko Kenso, 2012(11), 75-95. Expertise Required for School Library Staff Supporting Learning and Its Cultivation. 
Libraries today 2015, 53(1),19-24. Reading activities in MKC. Meiji University Library and Information Science Society Bulletin 2016,(7), 25-32. [all in Japanese] 